Капраль Ольга Ростиславівна кандидат економічних наук, асистент кафедри маркетингу та логістики, Національний університет «Львівська політехніка», вул. Ст. Бандери, 12, м. Львів, 79000, тел.: (096) 541-39-07, https://orcid.org/0000-0001-9636-0518

Яричевська Ярина Ігорівна студентка кафедри маркетингу та логістики, Національний університет «Львівська політехніка», вул. Степана Бандери, 12, м. Львів, 79000, тел.: (067) 886-53-00, https://orcid.org/0000-0001-9948-8621

\title{
ГЕЙМИФІКАЦІЯ У СФЕРІ ФІНТЕХ
}

Анотація. Динамічний розвиток сучасного суспільства зумовлює необхідність жорстокої конкурентної боротьби компаній за увагу потенційних та наявних клієнтів. 3 ростом онлайн сфери та збільшенням їі ваги у бізнесі, яка стрімко збільшилася у зв'язку 3 пандемією, ця боротьба суттєво загострилася. Все частіше компанії використовують різноманітні кросдисциплінарні інновативні підходи задля привернення уваги, а потім i втримання клієнта та збільшення його лояльності до компанії. Одним із найбільш популярних способів є геймифікація. Не зважаючи на ефективність даного методу, впровадження геймифікації чи іiі елементів у роботу підприємства пов'язано із певними складнощами, проаналізованими у статті, а також із стереотипами, які перешкоджають іiі інтеграції у традиційно консервативних сферах.

У даній статті розглянуто питання доцільності впровадження геймифікованих процесів у сферу фінансових технологій. Автори охарактеризували суть геймифікації, іiі роль у бізнесі, види, способи впровадження, мотиви підприємств та фактори, які призводять до імплементації ігрових підходів у неігрові системи та сценарії у бізнесі. Проаналізовано типи гравців, визначено їх мотиви та бажані винагороди. Також у процесі дослідження було визначено основні характеристики ігрової системи. У роботі також наведено переваги та недоліки впровадження геймифікації компанією, зокрема у сфері фінансових технологій.

Автори розглянули сферу фінансових технологій (фінтех), зокрема, типи фінтех компаній, які впроваджують геймифікацію у своїй діяльності. Найбільш доцільним, на думку авторів, $є$ застосування елементів геймифікації необанками, тобто банками, які надають фінансові послуги виключно онлайн, без створення фізичної мережі відділень. У роботі охарактеризовано моделі необанків та описано принципи, на яких повинна грунтуватися геймифікація 
маркетингу та продукту необанків. Імплементація процесів геймифікації у сфері фінансових технологій у даній статті розглянута на прикладі українського необанку Монобанк.

Ключові слова: геймифікація, фінансові послуги, фінтех, рівень залученості, лояльність.

Kapral Olha Rostyslavivna Candidate of Economic Sciences, Assistant of the Department of Marketing and Logistics, Lviv Polytechnic National University, St. Bandery St., 12, Lviv, 79000, tel .: (096) 541-39-07, https:// orcid.org/0000-0001-9636-0518

Yarychevska Yaryna Ihorivna Student of the Department of Marketing and Logistics, Lviv Polytechnic National University, St. Bandery St., 12, Lviv, 79000, tel .: (067) 886-53-00, https://orcid.org/0000-0001-9948-8621

\section{GAMIFICATION IN FINTECH}

Abstract. The dynamic development of modern society causes the need for the fierce competition of companies for the attention of potential and existing customers. With the growth of the online sphere and the increase in its weight in the business, which has increased rapidly due to the pandemic, this struggle has significantly escalated. Increasingly, companies are using a variety of cross-disciplinary innovative approaches to attract attention, and then keep the client and increase his loyalty to the company. One of the most popular ways is gamification. Despite the effectiveness of this method, the introduction of gamification or its elements into the work of the enterprise is associated with certain difficulties analyzed in the article, as well as stereotypes that impede its integration in traditionally conservative areas.

This article discusses the feasibility of implementing gaming processes in the field of financial technology. The authors described the essence of gamification, its role in business, types, methods of implementation, motives of enterprises, and factors that lead to the implementation of game approaches to non-game systems and scenarios in business. The types of players are analyzed, their motives and desired rewards are determined. Also, during the study, the main characteristics of the gaming system were determined. The paper also provides advantages and disadvantages of the implementation of gamification by the company, in particular in the field of financial technology.

The authors considered the field of financial technologies (fintech), in particular, the types of fintech companies that implement gamification in their activities. The most appropriate, according to the authors, is the use of gamification elements by non-banks, that is, banks that provide financial services exclusively online, without creating a physical network of branches. The paper describes the models of non-banks and describes the principles on which the gamification of 
marketing and the product of non-banks should be based. The implementation of gamification processes in the field of financial technologies in this article is considered in the example of the Ukrainian neobank Monobank.

Keywords: gamification, financial technologies, fintech, level of involvement, loyalty.

Постановка проблеми. У сучасному світі питання залучення нових клієнтів та забезпечення їх лояльності постійно загострюється. Ефективність застосування заходів стимулювання збуту постійно знижується. Важливим також є недоцільність застосування даних методів у певних сферах, наприклад, у сфері фінансових технологій. Важливим $є$ пошук нових рішень та підходів до вирішення даної проблеми. Зокрема, доцільно дослідити можливість застосування геймифікації, як засобу, який здатен не лише привабити клієнтів та забезпечити їх лояльність, але й сприяє побудові відкритого та інноваційно спрямованого бренду.

Аналіз останніх досліджень і публікацій. Геймифікацію як сучасний інструмент розвитку бізнесу та бізнес адміністрування розглянули у своїх роботах Чепка В. В. та Надзуга О. С., Соболєва Г. Г. та Панов В. А.

У якості ефективного заходу для роботи із персоналом, зокрема для здійснення ефективної адаптації та забезпечення лояльності, геймифікацію досліджували Насирова С. В., Уткіна Ю. М., Руських А. О.

Геймифікацію як засіб забезпечення лояльності споживачів розглянув у своїй роботі Присакар I. I. Як засіб бренд-комунікацій геймифікацію розглянули Ромат Є. В. та Білявська Ю. В.

Метою даної статті $є$ дослідження геймифікації як засобу залучення та втримання споживачів у забезпечення їх лояльності у сфері фінансових технологій.

Виклад основного матеріалу. Тенденції розвитку сучасного світу вимагають застосування крос-дисциплінарних та інновативних підходів у бізнесі для досягнення успіху. Одним із таких способів можна вважати геймифікацію - застосування ігрових методів у неігрових процесах. Геймифікацію застосовують в освітніх процесах, HR-процесах, бізнесадмініструванні тощо. Застосовують геймифікацію компанії різного рівня: маленькі компанії та стартапи зосереджуються на геймифікації продукту, середні компанії залучають споживачів, а крупні компанії адаптують персонал та покращують його продуктивність за допомогою геймифікації, проте мають місце також і змішані підходи.

Задля кращого розуміння процесу залучення користувачів 3 допомогою геймифікації слід розглянути типи гравців, подані у табл. 1. 
Типи гравців в геймифікації

\begin{tabular}{|c|c|c|c|c|}
\hline Тип гравця & Характеристика & Мотиви & $\begin{array}{l}\text { Тип } \\
\text { нагороди }\end{array}$ & Приклад \\
\hline Гравець & $\begin{array}{l}\text { Основний } \\
\text { цільовий сегмент } \\
\text { усіх існуючих } \\
\text { сценаріїв гри, } \\
\text { зацікавлені грою } \\
\text { заради гри }\end{array}$ & $\begin{array}{l}\text { Нагороди та } \\
\text { сама гра, } \\
\text { основна ціль - } \\
\text { пройти рівень }\end{array}$ & Зовнішній & $\begin{array}{l}\text { Карти } \\
\text { героїв із } \\
\text { доповненою } \\
\text { реальністю } \\
\text { в АТБ }\end{array}$ \\
\hline Комунікатор & $\begin{array}{lr}\text { Зважають на } \\
\text { соціальний статус, } \\
\text { перебувають } \\
\text { пошуку людей } \\
\text { схожими } \\
\text { iнтересами } \\
\text { статусом }\end{array}$ & $\begin{array}{lr}\text { Відносини } & 3 \\
\text { друзями у грі, } \\
\text { спілкування } \\
\text { взаємодія, } \\
\text { залученість } \\
\text { спільноти }\end{array}$ & Внутрішній & $\begin{array}{l}\text { Клуби за } \\
\text { інтересами } \\
\text { в системі } \\
\text { мотивації } \\
\text { персоналу }\end{array}$ \\
\hline Творець & $\begin{array}{lr}\text { Не терплять правил } \\
\text { та обмежень, } \\
\text { прагнуть } \\
\text { обирати } \\
\text { розвитку у у } \\
\text { Основя } \\
\text { сріні. } \\
\text { сегмент соцмереж } \\
\end{array}$ & $\begin{array}{l}\text { Автономія, } \\
\text { самодостатність, } \\
\text { здатність } \\
\text { створювати та } \\
\text { досліджувати }\end{array}$ & Внутрішній & $\begin{array}{l}\text { Instagram, } \\
\text { Facebook }\end{array}$ \\
\hline Ачівер & $\begin{array}{l}\text { Концентруються на } \\
\text { професійному } \\
\text { розвитку «для } \\
\text { себе» за умов } \\
\text { зацікавленості, } \\
\text { перешкоди у грі є } \\
\text { додатковим } \\
\text { викликом та } \\
\text { частиною мотивації }\end{array}$ & $\begin{array}{l}\text { Влада, } \\
\text { натхнення } \\
\text { викликами, } \\
\text { прагнення до } \\
\text { майстерності } \\
\text { лідерства }\end{array}$ & Внутрішній & $\begin{array}{l}\text { Системи } \\
\text { мотивації } \\
\text { персоналу, } \\
\text { спрямовані } \\
\text { на } \\
\text { постійний } \\
\text { розвиток } \\
\text { навичок }\end{array}$ \\
\hline Філантроп & $\begin{array}{lr}\text { Прагнуть } & \text { стати } \\
\text { частиною } & \text { чогось } \\
\text { більшого } & \text { i } \\
\text { важливого, грають } \\
\text { заради } \\
\text { мети }\end{array}$ & $\begin{array}{lr}\text { Альтруїзм, } \\
\text { бажання стати } \\
\text { кращими } & \text { для } \\
\text { співгравців } & \text { без } \\
\text { очікування } & \\
\text { нагороди } & \end{array}$ & Внутрішній & $\begin{array}{l}\text { Wikipedia, } \\
\text { Quora }\end{array}$ \\
\hline
\end{tabular}

Джерело: на основі $[1,2]$ 
Важливо відзначити, що хоч задля позначення процесу взаємодії із геймифікованою системою використовують термін «гра», сама по собі геймифікація не є створення гри як такої і гра не виступає ціллю при впровадженні елементів геймифікації у роботу організації чи в продукт. У даному процесі має місце перенесення позитивних характеристик, елементів та механізмів ігрового процесу [3].

Основними складовими геймифікованої системи, завдяки яким відбувається залучення та втримання користувача, $є$ змагальницький дух, наявність системи накопичення балів та можливість отримання винагороди, проте для побудови ефективної ігрової системи у бізнесі важливим $\epsilon$ визначення також ключових характеристик ефективності (табл. 2).

Таблиияя 2

Ключові характеристики ефективної ігрової системи

\begin{tabular}{|l|l|}
\hline Характеристика & Сутність \\
\hline $\begin{array}{l}\text { Відсутність примусу } \\
\text { (добровільність) }\end{array}$ & $\begin{array}{l}\text { Гравець повинен самостійно приймати рішення про } \\
\text { вступ в ігорвий процес, інакше чинитиме спротив } \\
\text { нав'язаній грі, не матиме достатнього інтересу }\end{array}$ \\
\hline $\begin{array}{l}\text { Наявність кількох } \\
\text { рівнів у системі }\end{array}$ & $\begin{array}{l}\text { Наявність системи рівнів забезпечить участь у грі } \\
\text { протягом довшого часу, підкріпить мотивацію та } \\
\text { посилить інтерес, за умови правильної побудови } \\
\text { складності (перейти на наступний рівень не надто } \\
\text { легко і не надто складно) }\end{array}$ \\
\hline Наявність винагороди & $\begin{array}{l}\text { Регулярна винагорода за будьякі успіхи є запорукою } \\
\text { збереження мотивації гравця, при чому винагорода } \\
\text { повинна бути різних типів: нові можливості у грі, } \\
\text { звання, елементи кастомізації тощо }\end{array}$ \\
\hline $\begin{array}{l}\text { Наявність соціальної } \\
\text { взаємодії }\end{array}$ & $\begin{array}{l}\text { Наявність ігрового соціуму необхідна для } \\
\text { забезпечення комфорту гравця та збільшення } \\
\text { мотивації за рахунок спілкування та конкуренції } 3 \\
\text { іншими учасниками гри }\end{array}$ \\
\hline $\begin{array}{l}\text { Перманентне } \\
\text { оновлення контенту }\end{array}$ & $\begin{array}{l}\text { Для підтримки інтересу користувача на необхідному } \\
\text { рівні потрібне постійне оновлення контенту гри }\end{array}$ \\
\hline
\end{tabular}

Джерело: на основі [4]

Геймифікація базується на застосуванні методів, які залучають природні інстинкти, а саме: конкуренцію, яка в подальшому веде також до залучення потреб вищого рівня згідно піраміди А. Маслоу: прагнення до звершень (досягнень), статусності, самовираження, егоїстичного альтруїзму, розв'язання задач. Основою геймифікації $\epsilon$ власне розв'язання задач або виконання різноманітних ігрових завдань, за які гравець отримує винагороду різних типів та рівнів, залежно від складності завдання та уже отриманих призів чи вирішених ігрових проблем. Заохоченнями у геймифікації виступають бали, відзнаки, рівні, індикатори прогресу. Важливою складовою геймифікації також є сторітеллінг. 


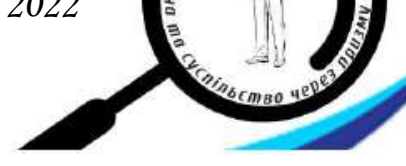

Мотивами впровадження геймифікації в бізнес виступають [3]:

- постійно зростаюча потреба суспільства у нових враженнях та досвіді;

- символізація багатьох сфер життя;

- вдосконалення та здешевлення інформаційних технологій;

- динамічні ринкові зміни, пов'язані із переходом в онлайн сферу.

Особливо ефективним застосування геймифікації $\epsilon$ при роботі iз споживачами «покоління Z» та «міленіалами» [1].

Серед переваг впровадження геймифікації (як зовнішньої, спрямованої на продукт чи маркетинг, так і внутрішньої, спрямованої на працівників компанії) збільшення рівня залученості, задоволеності, створення відчуття причетності. Серед недоліків варто виділяти часто короткочасний ефект геймифікації, необхідність узгодження цілей геймифікації із цілями організації та, іноді, дещо поверхневий характер геймифікації [3].

Найпростіше інтегрувати в роботу організації геймифікацію, спрямовану на персонал. Геймифікація продукту та геймифікація маркетингу є складнішими для впровадження у «неігрові» сфери підприємництва та вимагає інновативних підходів до розробки продукту та комплексу маркетингу загалом. Однією із сфер, де згідно традиційних підходів, найскладніше імплементувати елементи геймифікації, $є$ сфера фінансових послуг. Саме тому важливим є сфера фінтеху, де впровадження геймифікацієї є значно простішим та більш доцільним.

Фінтех або фінансові технології $\epsilon$ найбільш швидко зростаючим сегментом фінансових послуг сучасності. Перш за все це забезпечується стрімкою цифровізацією усіх сфер та галузей. Окрім цього, фінтех є однією із найбільш інноваційних галузей: технологічний розвиток супроводжується новітніми підходами до організаційних та продуктових складових бізнесу [5].

Фактично фінтех $є$ поєднанням фінансових послуг та фінансової діяльності та інформаційних послуг. Фінтех проник у всі сфери фінансової галузі: управління персональними фінансами (CreditKarma, Mint, BillGuard), платежі (Stripe, Square, Wepay), кредити (LendingClub, Kabbage, Prosper), акції (CircleUp, Loyal3), грошові перекази (Azimo, Payoneer, Currencyfair), ритейл інвестування (Motif, Kapitall, Wealthfront), інституційне інвестування (Addepar, SumZero), краудфандинг (Kickstarter, Indiegogo), онлайн-банкінги (Cardlike, Simple, Moven, Atom), бізнес засоби (Gusto, Xero, Zenpayroll), інфраструктуру (DemystData, Plaid, Mambu), безпеку (Centrify, Riskifield, Signifyd, Feedzai), аналітику та дослідження (Seeking Alpha, Cosser, Xignite, Heckyl).

Очевидно, що геймифікація не доцільна для застосування у всіх сферах фінтеху. Геймифікацію у цій сфері застосовують для підвищення фінансової грамотності населення, наданні консультацій щодо управління власними фінансами, для популяризації окремих інновацій, зокрема інтернет-банкінгу тощо [6]. На думку авторів, найбільш логічним є застосування геймифікації при управлінні особистими коштами, онлайн-банкінгах та у необанках.

Необанком виділяють як сучасний тип банку, який працює виключно 
онлайн та без традиційних фізичних відділень, при цьому надаючи усі банківські послуги. Згідно даних досліджень Business Insider Intelligence, вартість необанків у 2024 р., порівняно із 2018 р., зросте втричі (рис. 1), а кількість користувачів вчетверо (рис. 2).

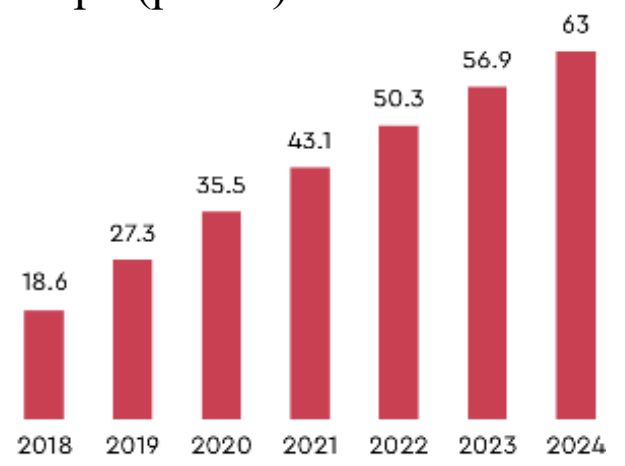

Pис.1. Прогноз вартості необанків до 2024 р. (у млрд. дол. США) Дюерело: [7]

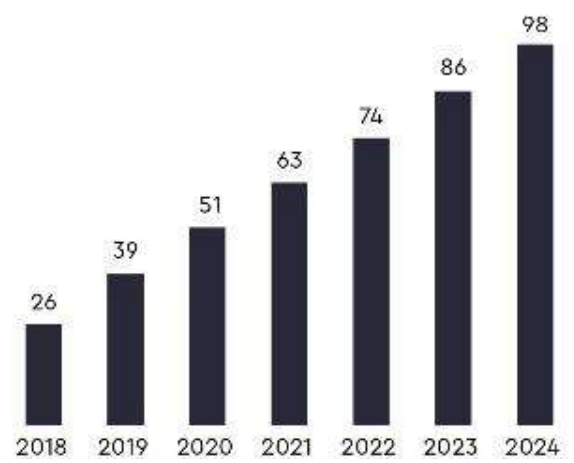

Рис. 2. Прогноз кількості користувачів необанків до 2024 р. (млн. ос.) Дюерело: [7]

Незважаючи на існування кількох моделей необанків (табл. 1) геймифікація доцільна для застосування у всіх із них.

Таблицяя 3

\section{Моделі необанків}

\begin{tabular}{|c|c|c|}
\hline Модель & Приклад & Сутність \\
\hline $\begin{array}{l}\text { Модель } \\
\text { використанням } \\
\text { повноцінної } \\
\text { банківської } \\
\text { ліцензї }\end{array}$ & $\begin{array}{l}\text { Monzo } \\
\text { (Великобританія) }\end{array}$ & $\begin{array}{l}\text { Наявна повна банківська ліцензія, регуляція } \\
\text { не відрізняється від стандартної банківської. } \\
\text { В певних країнах для необанків створені } \\
\text { обмежені ліцензії як проміжний етап перед } \\
\text { отриманням повноцінної. }\end{array}$ \\
\hline $\begin{array}{l}\text { Модель } \\
\text { кооперації } \\
\text { iншим банком }\end{array}$ & Chime (США) & $\begin{array}{l}\text { Зобов'язання щодо } \\
\text { нормативних вимог разом із кредитними } \\
\text { ризиками лежать на банкові-парнерові, } \\
\text { необанк надає лише технологічні рішення. }\end{array}$ \\
\hline $\begin{array}{l}\text { Змішана } \\
\text { модель }\end{array}$ & Bnext (Іспанія) & $\begin{array}{l}\text { Наявна ліцензія лише на деякі фінансові } \\
\text { послуги, решта діяльності ведеться через } \\
\text { партнера. }\end{array}$ \\
\hline
\end{tabular}

Джерело: на основі [8] 
Одним із небагатьох необанків, які використовують геймифікацію, є український мобільний банк Монобанк.

Монобанк - перший український необанк, заснований у 2017 р., на базі банківської ліцензії Universal Bank розробницькою компанією Fintech Band. CEО компанії Олег Гороховський стверджує, що Монобанк слід оцінювати як IT-компанію з мультиплікатором 10-12 до прибутку і заявляє вартість проекту (Fintech Band та Universal Bank, у периметрі якого є Монобанк) на суму понад мільярд доларів США [9].

У додатку наявні секретні ігри («Кіт-сосика»: символ Монобанку QR-кіт у вигляді змійки як у популярній одноіменній грі їсть українські банки та не повинен їсти НБУ, та «Space Invander», де QR-кіт летить на ракеті у космос, ловить інших котів та ухиляється від коронавірусу), нагороди за витрати певних категорій за кількістю чи сумами, послідованістю дій тощо. При цьому, у додатку можна відстежити свій приблизний рівень, порівняно із іншими користувачами, а нагороди витрати на купівлю мерчу (брендованої продукції) компанії. Також періодично компанія проводить змагання серед гравців у ігри чи при відкритті нового сезону нагород.

СЕО Монобанку, О. Гороховський, розглядає геймифікацію як один iз найважливіших елементів емоційного клієнтського сервісу [10].

Важливим елементом геймифікації у Монобанку $є$ добровільність, яка дозволяє людям, які не бажають грати в ігри в «серйозній» сфері фінансових послуг, разом 3 тим, ефект «секретності» ігор гарантує азарт та інтерес у споживачів-новаторів.

Варто розглянути також переваги та недоліки застосування геймифікації у сфері фінтех. Серед переваг:

- збільшення впізнаваності;

- залучення нових користувачів;

- ріст інтересу до компанії потенційних користувачів та наявних до продукту;

- зростання лояльності споживачів;

- отримання конкурентної переваги;

- характерна риса УТП.

Серед недоліків:

- можливий відтік консервативних клієнтів, для яких неприйнятна геймифікація «серйозної» сфери;

- складність технічного забезпечення та розробки самої ігрової системи, психологічного аналізу споживачів тощо;

- необхідність постійних оновлень контенту, рівнів, розробки нових ігор.

Варто розглянути основні принципи застосування геймифікації в сфері фінтех, а саме необанками, подані у табл. 4. 
Основні принципи застосування геймифікації необанками (на прикладі Монобанку)

\begin{tabular}{|c|c|c|}
\hline Принцип & Характеристика & Приклад \\
\hline $\begin{array}{l}\text { Визначення } \\
\text { цілей }\end{array}$ & \begin{tabular}{lr} 
Виокремлення & \multicolumn{2}{l}{ тактичних } \\
цілей (підвищення рівня \\
залученості, зацікавленості, \\
впізнаваності, лояльності \\
тощо), оскільки стратегічні \\
цілі досягаються комплексом \\
взаємодії геймифікації, якості \\
продукту, \\
затребуваності \\
функціоналу, потреб та вимог \\
споживачів і ринку тощо.
\end{tabular} & $\begin{array}{l}\text { Iнтеграція геймифікації у } \\
\text { роботу Монобанку збільшило } \\
\text { рівень зацікавленості } \\
\text { компанісю, спричинило ріст } \\
\text { iнтересу та обізнаності } \\
\text { потенційних споживачів (т. з. } \\
\text { «хайп»), забезпечило } \\
\text { збереження інтересу наявних } \\
\text { користувачів, ріст рівня } \\
\text { лояльності. }\end{array}$ \\
\hline $\begin{array}{l}\text { Опис бажаної } \\
\text { для } \\
\text { підприємства } \\
\text { поведінки } \\
\text { споживачів- } \\
\text { гравців із } \\
\text { забезпеченням } \\
\text { умов }\end{array}$ & $\begin{array}{l}\text { Для забезпечення бажаного } \\
\text { рівня залученості у гру } \\
\text { необхідно п् прописати } \\
\text { алгоритм дій гравців та } \\
\text { забезпечити технічні умови } \\
\text { для цього, наприклад, } \\
\text { якісний UX/UI дизайн }\end{array}$ & $\begin{array}{l}\text { Компанія забезпечила } \\
\text { високу якість роботи свого } \\
\text { додатку, служби підтримки, } \\
\text { адаптивний } \\
\text { (нагорода Red Dot), якісний } \\
\text { UX/UI дизайн, а самі ігри } є \\
\text { простими та інтуїтивно } \\
\text { зрозумілими у використанні }\end{array}$ \\
\hline $\begin{array}{l}\text { Характеристика } \\
\text { типології } \\
\text { потенційних } \\
\text { гравців }\end{array}$ & $\begin{array}{l}\text { Зважаючи на різницю у } \\
\text { мотивації та підході до гри у } \\
\text { різних типів гравців слід } \\
\text { підібрати та забезпечити у } \\
\text { наявності потрібну для } \\
\text { кожного типу гравців } \\
\text { мотивацію, винагороди, } \\
\text { спосіб ведення гри тощо }\end{array}$ & $\begin{array}{l}\text { Нагороди у грі є різними за } \\
\text { складністю, способом } \\
\text { досягнення, ігри є } \\
\text { «секретними» (прихованими } \\
\text { в інтерфейсі додатку), тому } \\
\text { здатні втримати інтерес } \\
\text { різних типів гравців }\end{array}$ \\
\hline $\begin{array}{l}\text { Розробка } \\
\text { циклів } \\
\text { активності } \\
\text { гравців }\end{array}$ & 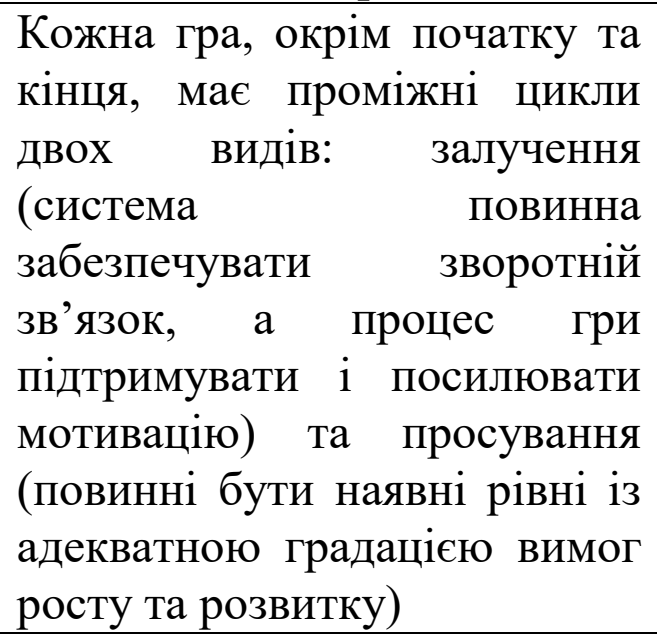 & $\begin{array}{lr}\text { Деякі нагороди } & \text { логічним } \\
\text { продовженням попередніх, } \\
\text { не всі } & \text { нагороди } \\
\text { відкриваються одночасно, } \\
\text { рейтинг користувача в грі } \\
\text { постійно оновлюється }\end{array}$ \\
\hline
\end{tabular}




\begin{tabular}{|c|c|c|}
\hline $\begin{array}{l}\text { Вибір } \\
\text { інструментів } \\
\text { для } \\
\text { імплементацї } \\
\text { інструментів } \\
\text { геймифікації }\end{array}$ & 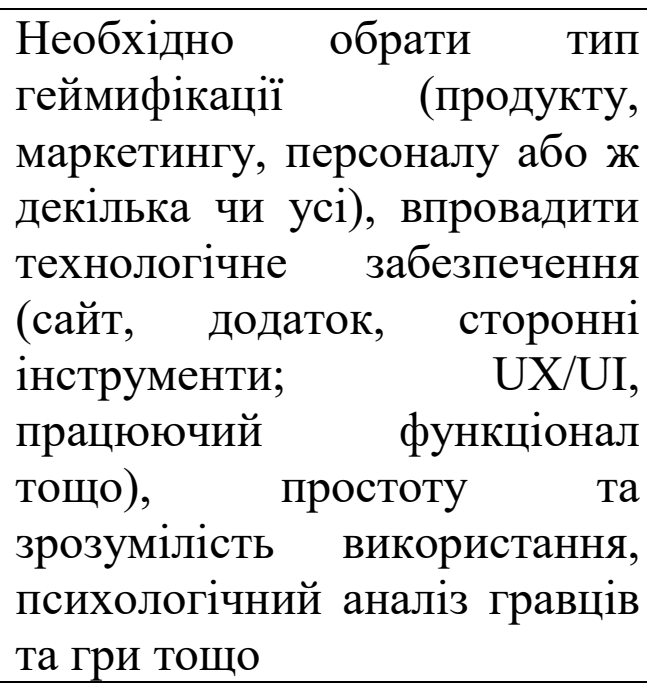 & $\begin{array}{l}\text { Компанія обрала шлях } \\
\text { геймифікації продукту, що } \\
\text { забезпечило високий рівень } \\
\text { інтересу до компанії зі } \\
\text { сторони громадськості та } \\
\text { потенційних споживачів, а } \\
\text { рівень технічного } \\
\text { забезпечення є одним із } \\
\text { найкращих серед необанків } \\
\text { України }\end{array}$ \\
\hline $\begin{array}{ll}\text { Аналіз } & \text { ігро } \\
\text { рутини } & \end{array}$ & 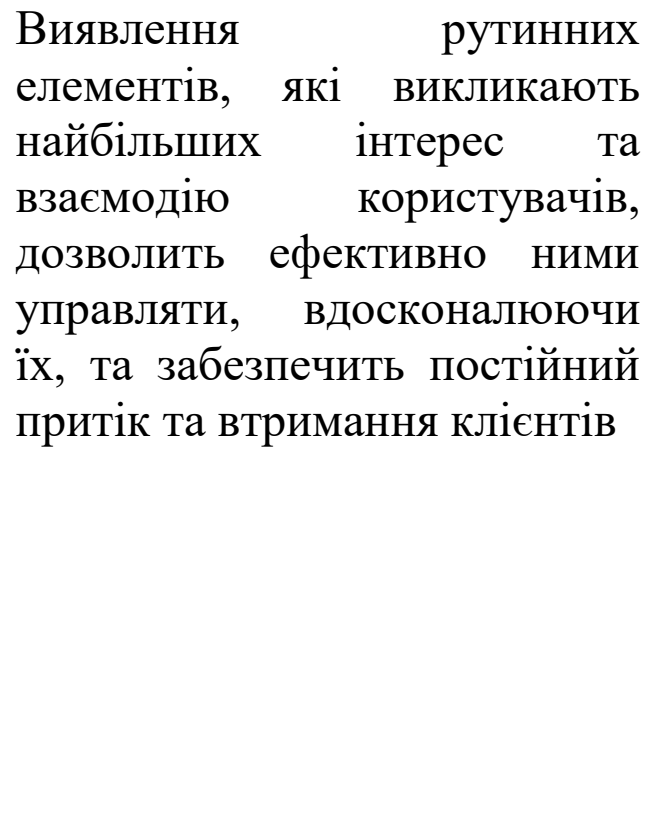 & $\begin{array}{l}\text { Першопочатково компанія не } \\
\text { планувала введення реальних } \\
\text { стимулів за участь в іграх, } \\
\text { проте помітивши високий } \\
\text { рівень інтересу споживачів, } \\
\text { визначила терміни та вартісні } \\
\text { в реальному світі винагороди, } \\
\text { активізувавши змагання та } \\
\text { збільшивши залученість у } \\
\text { гру, а також продовжила } \\
\text { розробляти рівні, ігри та } \\
\text { нагороди, зважаючи на ті } \\
\text { ігрові елементи, } \\
\text { викликали найбільш значущу } \\
\text { реакцію користувачів }\end{array}$ \\
\hline $\begin{array}{l}\text { Розробка } \\
\text { механізму } \\
\text { заохочення } \\
\text { гравців }\end{array}$ & 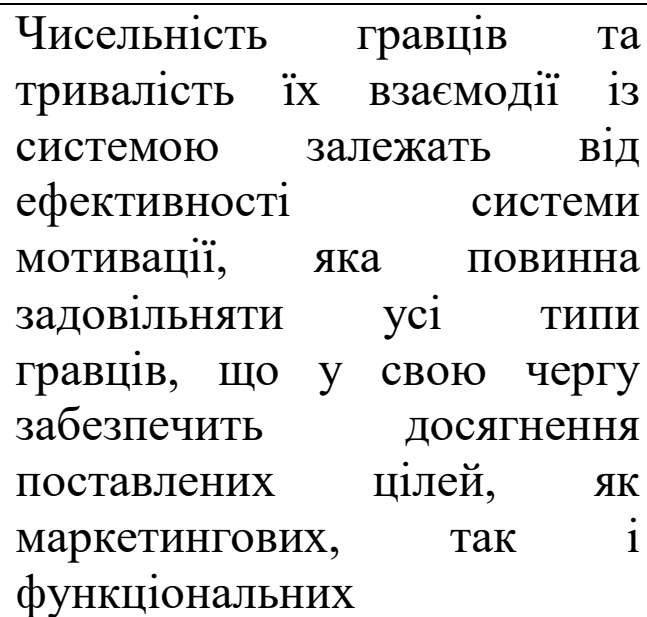 & $\begin{array}{lr}\text { Завдяки введенню } & \text { великої } \\
\text { кількості } & \text { нагород, які } \\
\text { вимагають } & \text { здійснення } \\
\text { різних дій } & \text { (наприклад, } \\
\text { покупок у у } & \text { певних } \\
\text { категоріях), } & \text { компанія } \\
\text { забезпечила } & \text { інтерес } \\
\text { більшості } & \text { своїх } \\
\text { користувачів до гри } & \end{array}$ \\
\hline $\begin{array}{l}\text { Постійне } \\
\text { оновлення } \\
\text { контенту }\end{array}$ & $\begin{array}{l}\text { Регулярне оновлення вмісту } \\
\text { системи забезпечить сталий } \\
\text { інтерес гравців та подовжить } \\
\text { ігровий цикл }\end{array}$ & $\begin{array}{l}\text { Компанія постійно додає } \\
\text { нові нагороди, реалізує нові } \\
\text { ігри }\end{array}$ \\
\hline
\end{tabular}




\begin{tabular}{|c|c|c|}
\hline $\begin{array}{l}\text { Створення } \\
\text { стимулів } \\
\text { гравців }\end{array}$ & $\begin{array}{l}\text { Ігрова мотивація є потужним } \\
\text { рушієм інтересу та рівня } \\
\text { залученості до гри, проте } \\
\text { користувачі потребують } \\
\text { також стимулів, цінних у } \\
\text { реальному житті та } \\
\text { придатних до використання }\end{array}$ & $\begin{array}{l}\text { За допомогою зібраних } \\
\text { нагород можна придбати } \\
\text { мерч компанії, за першість у } \\
\text { швидкості збору нагород чи } \\
\text { досягнення певного рівня у } \\
\text { секретних іграх пропонують } \\
\text { різні нагороди (квитки на } \\
\text { Олімпійські ігри, кубки } \\
\text { Європи з футболу, айфони } \\
\text { тощо) }\end{array}$ \\
\hline $\begin{array}{l}\text { Персоніфік } \\
\text { гри }\end{array}$ & $\begin{array}{l}\text { Персоніфікація }- \text { потужний } \\
\text { елемент залучення та } \\
\text { збільшення } \\
\text { користувача, щояльності } \\
\text { досягається за до грі } \\
\begin{array}{l}\text { персоніфікованих нагорог, } \\
\text { стимулів, рейтингів тощо }\end{array}\end{array}$ & 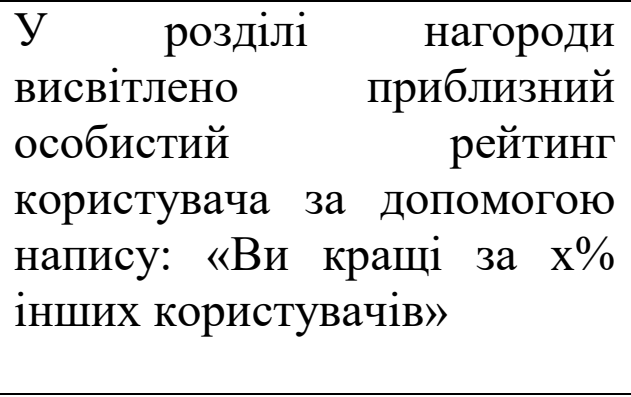 \\
\hline $\begin{array}{l}\text { Забезпечення } \\
\text { можливостей } \\
\text { для росту та } \\
\text { розвитку } \\
\text { гравців у грі }\end{array}$ & $\begin{array}{l}\text { Відповідно до типу гравців } \\
\text { необхідно } \\
\text { ефективні системи досягнення } \\
\text { ігрових цілей, оновлювати цілі, } \\
\text { рівні тощо }\end{array}$ & 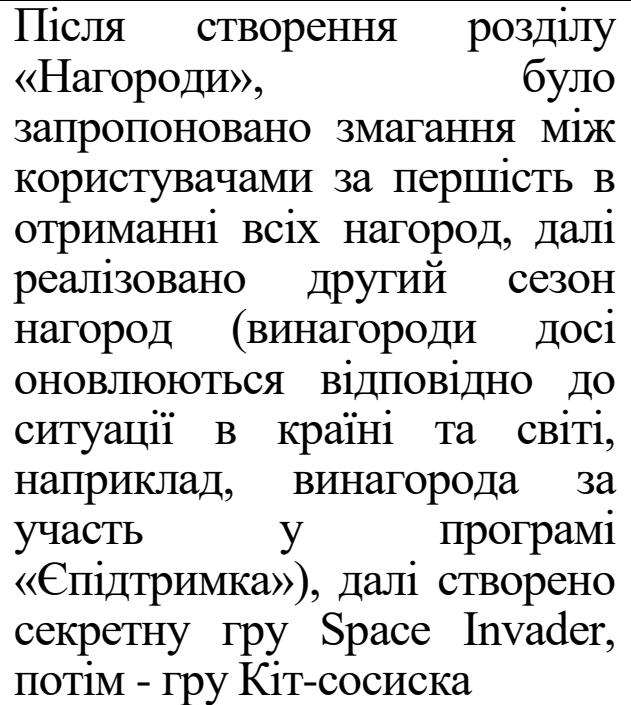 \\
\hline
\end{tabular}

Джерело: розроблено авторами на основі [11]

Висновки. На сучасному етапі розвитку ринку, застосування підходів із різних сфер може стати вагомою конкурентною перевагою та забезпечити успіх на ринку. Застосування геймифікації як продукту, так і маркетингу, бізнес-адміністрування та адаптації персоналу здатне виділити компанії, привернути до неї увагу та призвести до зростання ефективності та прибутковості. Зважаючи на постійну цифровізацію бізнесу, посилену пандемією та карантинними обмеженнями, а також тим, що споживачі «покоління Z» та «покоління Y» (міленіали) стають все більш важливим сегментом для бізнесу, доцільним $є$ застосування геймифікації у традиційно консервативних сферах підприємництва, наприклад, у сфері фінтех. Інтеграція 
геймифікованих процесів та інструментів у бізнес забезпечить зростання кількості споживачів, їх втримання, а в подальшому їх лояльність.

Важливим, окрім прийняття рішення про імплементацію геймифікації у роботу компанії, також $\epsilon$ забезпечення технологічної сторони процесу на відповідному рівні та чітко продумана стратегія гри, визначення цілей геймифікації, типів гравців, їх мотивації тощо.

\section{Jimepamypa:}

1. Ромат С. В. Гейміфікація та іiі сприйняття поколінням «Z»/ $\mathrm{C}$. В. Ромат, Ю. В. Білявська // Наукові записки Національного університету «Острозька академія», серія «Економіка». - 2020. - № 17 (45). - С. 23-28.

2. Чепка В. В. Геймифікація: сучасний інструмент розвитку бізнесу / В.В. Чепка, О.С. Надзуга // Сучасні аспекти розвитку фінансових та інноваційно-інвестиційних процесів. Збірник тез наукових робіт учасників міжнародної науково-практичної конференції для студентів, аспірантів та молодих вчених, 2018. - С. 73-75.

3. Уткіна Ю. М. Геймифікація: потенціал застосування, роль і місце в розвитку підприємства / Ю. М. Уткіна, А. О. Руських // Вісник економіки, транспорту і промисловості. - 2019. - № 66. - С. 139-148.

4. Годван Д. Ф. Геймификация. Применение игровых систем в бизнесе / Д.Ф. Годван // Бизнес-образование в экономике знаний. - 2019. - № 2. - С. 28-31.

5. Котляров И. Д. Финтех: сущность и модели реализации. / И.Д. Котляров. - С. - П.: ЭКО, 2018. - № 12. - С. 23-39.

6. Кошман I. В. Інноваційні послуги фінансових посередників / I. В. Кошман, Т. П. Гудзь. // Актуальні питання розвитку економіки, харчових технологій та товарознавства. Тези доповідей XXXIX наукової студентської конференції за підсумками науково-дослідних робіт студентів за 2015 рік. - 2016. - С. 24-27.

7. Офіційний сайт Business Insider Intelligence. [Електронний ресурс]. - Режим доступу: https://www.businessinsider.com/research.

8. Офіційний сайт інтернет-видання Ain.ua. Что такое «необанки» и почему это новое будущее после коронавируса. [Електронний ресурс]. - Режим доступу: https://ain.ua/ru/2020/06/02/chto-takoe-neobanki-i-pochemu-eto-novoe-budushhee-posle-koronavirusa/

9. Офіційний сайт інтернет-видання НВ Бізнес. Думки на мільярд. Чому monobank не боїться конкурентів з АТБ та Rozetka, i скільки він коштує - інтерв'ю з Олегом Гороховським. [Електронний ресурс]. - Режим доступу: https://biz.nv.ua/ukr/finance/oleg-gorohovskiy-pro-dohodimonobank-tigipko-universal-bank-ta-fintech-band-interv-yu-50204338.html

10. Офіційний Telegram канал Олега Гороховського ОГо!. [Електронний ресурс]. Режим доступу: https://t.me/OGoMono

11. Присакар I. I. Гейміфікація: ефективна технологія впливу на лояльність споживачів ресторанних послуг. / І. І. Присакар // Економіка і суспільство. - 2016. - № 4. - С. 179-185.

\section{References:}

1. Romat, Ye.V., \& Bilyavska, Yu.V. (2020). Heymifikatsiya ta yiyi spryynyattya pokolinnyam «Z» [Gamification and its perception by generation "Z"]. Naukovi zapysky Natsional'noho universytetu «Ostroz'ka akademiya», 17 (45), 23-28 [in Ukrainian].

2. Chepka, V.V., \& Nadzuga, O.S. (2018). Heymyfikatsiya: suchasnyy instrument rozvytku biznesu [Gamification: a modern tool for business development]. Suchasni aspekty rozvytku finansovykh ta innovatsiyno-investytsiynykh protsesiv. Zbirnyk tez naukovykh robit uchasnykiv 
mizhnarodnoyi naukovo-praktychnoyi konferentsiyi dlya studentiv, aspirantiv ta molodykh vchenykh, 73-75 [in Ukrainian].

3. Utkina, Yu.M., \& Ruskyh, A.O. (2019). Heymyfikatsiya: potentsial zastosuvannya, rol' i mistse $\mathrm{v}$ rozvytku pidpryyemstva [Gamification: potential of application, role and place in the development of the enterprise]. Visnyk ekonomiky, transportu i promyslovosti, 66, 139-148 [in Ukrainian].

4. Godvan D. F. (2019). Geymifikatsiya. Primeneniye igrovykh sistem v biznese [Gamification. The usage of the game systems in the business]. Biznes-obrazovaniye v ekonomike znaniy, 2, 28-31 [in Russian].

5. Kotlyarov I. D. (2018). Fintekh: sushchnost' i modeli realizatsii [Fintech: essence and models of realization]. Sankt-Peterburg: EKO, 12, 23-39 [in Russian].

6. Koshman, I.V., \& Hudz, T.P. (2016). Innovatsiyni posluhy finansovykh poserednykiv [Innovative services of financial intermediaries]. Aktual'ni pytannya rozvytku ekonomiky, kharchovykh tekhnolohiy ta tovaroznavstva. Tezy dopovidey XXXIX naukovoyi student·s'koyi konferentsiyi za pidsumkamy naukovo-doslidnykh robit studentiv za 2015 rik. 24-27 [in Ukrainian].

7. The official website of Business Insider Intelligence. Retrieved from: https://www.businessinsider.com/research [in English].

8. The official website of the Internet edition Ain.ua. What is the "neobank" and why it is a new future after the coronavirus. Retrieved from: https://ain.ua/ru/2020/06/02/chto-takoe-neobankii-pochemu-eto-novoe-budushhee-posle-koronavirusa/ [in Russian].

9. The official website of the online publication NV Business. Thoughts for a billion. Why monobank is not afraid of competitors from ATB and Rozetka, and how much it costs - an interview with Oleg Gorokhovskyi. Retrieved from: https://biz.nv.ua/ukr/finance/oleggorohovskiy-pro-dohodi-monobank-tigipko-universal-bank-ta-fintech-band-interv-yu50204338.html [in Ukrainian].

10. The official Telegram channel of Oleg Goryokhovskyi OGo!. Retrieved from: https://t.me/OGoMono f [in Ukrainian].

11. Prysakar I. I. (2016). Heymifikatsiya: efektyvna tekhnolohiya vplyvu na loyal'nist' spozhyvachiv restorannykh posluh [Gamification: effective technology of influence on loyalty of consumers of restaurant services]. Ekonomika i suspil'stvo, 4, 179-185 [in Ukrainian]. 